clearest insight into the processes that have been employed and the reason for the direction which progress has taken. It is a long cry from the ancient Greek to the modern physicist, from Aristotle to Pasteur, and by a few scanty references to the work of eminent men in past centuries we do not get any continuous picture of the growth of any one science, be it physics or chemistry, zoology or botany, geology or astronomy, for all these and some others figure within the modest compass the author allows himself.

A comparison with Ostwald's “ Klassiker der Exacten Wissenschaften " would be inevitable, even if the author had not frequently directed attention to that work, and occasionally availed himself of its contents. Such comparison is, however, to the disadvantage of the present work. In that case, the classics of science hitherto accessible only to the few were made available to the many. Specialists, each eminent in his own branch of science, were responsible for the presentation of the work, each in his own department, to which ample space was allotted. But here the only arrangement that can be recognised is roughly chronological, and the student is led from subject to subject without leisure to concentrate his attention upon any. Perhaps there is no great reason to quarrel with the choice of researches the author has made in order to illustrate particular phases in the history of discovery. No selection could be entirely satisfactory when there is overlapping of research or contemporaneous advance. Why, for example, should Torricelli be omitted and Guericke appear, or Celsius be chosen in preference to Reaumur? Sir William Herschel finds a place, Bradley does not; Chladni discusses the origin of meteors, Schiaparelli is passed over in silence. One might ask whether Humboldt and Goethe fairly come within this scheme, or whether Darwin is adequately represented by an extract from the "Journal of the Beagle," or Helmholtz by a quotation from a popular lecture? But it would be unfair not to remember and admit that this work is only a portion of a larger treatise. It is the first volume of a "Grundrisz einer Geschichte der Naturwissenschaften," and possibly if the whole treatise were before us the scheme could be better appreciated.

\section{SANITARY SCIENCE.}

The Essentials of Sanitary Science. By Gilbert E. Brooke. Pp. xii +4 I3. (London : Henry Kimpton, 1909.) Price $6 s$, net.

THE author of this work states in his preface that he hopes it will meet its aim of covering all the necessary ground for the student preparing for the diploma of public health, and that he has endeavoured to make it as useful in the laboratory as in the study; furthermore, he hopes it may also be useful to sanitary officers and medical officers of the public services. A glance suffices to make it plain that he has not achieved his aim. $\mathrm{He}$ has failed because he attempted the impossible when he set himself the task of covering the whole range of the science and practice of hygiene and public health within the narrow compass of a small, handy volume. The work is, in fact, little more than a digest or summary, which is not suited to the student's needs, and the lack of detail is also an essential respect in which it will fail to meet the needs of the publichealth official. It is not sufficient, for instance, to tell the student for the diploma of public health that in reference to the working of a barometer, corrections have to be made for capillarity, temperature, and altitude (p. 29), when his examiners expect him to know how these corrections are made; nor is it sufficient to offer a sanitary official, presumably for reference purposes, a digest of sanitary law in which the whole of the important and complicated subject of legislation dealing with the food supply is dismissed in a page and a half of printed matter.

Although the general scrappiness of the information so materially limits the value of the book to the student and practitioner alike, it possesses some good points which add to one's regret at having to criticise unfavourably the work as a whole. Little fault can be found with the selection made of the material dealt with. Indeed, for the most part it is wise and in good proportion; but a glaring exception to this rule is to be noted in the case of tuberculosis, which is not mentioned in the index, and is only referred to in connection with dust and milk in the text of the book. Again, there are few instances of inaccuracies - the faults of commission, in fact, sink into insignificance before the all-prevailing faults of omission; but an insufficient statement of the subject is often responsible for leading the student by implication to erroneous conceptions. In this connection the author's attention is directed to the fact that for the purpose of aërobic bacteriolysis it is not usual to put a layer of sand on the top of the filter and another layer at the bottom immediately over the effluent pipes; nor is the average composition of crude sewage in this country represented by albuminoid ammonia in the amount of $0^{\circ} 28$ of a part per 100,000.

It is conceded that a vast amount of information is comprised within the small compass of the work, but it is information of a scrappy and incomplete order, and information in respect of which essentials, both from the standpoint of the student and practitioner, are omitted. As evidence of the justice of this statement it is not necessary to do more than direct the reader's attention to the fact that the bacteriological examination of water is dismissed in three and a half pages, or not much more than roo lines of print; that to the chemical examination of disinfectants three-quarters of a page of printed matter is devoted, and carbolic acid is the only disinfectant dealt with; and that the important subject of school hygiene, the importance of which to the public-health student cannot well be exaggerated now that the Education (Administrative Provisions) Act is a force in the land, is dismissed in four pages.

Dr. G. E. Brooke has had experience both as a health officer and a teacher, and is the author of one or two useful handbooks, and he must realise that this work stands in need of a considerable extension if it is to meet the objects for which it was designed. 